\title{
FEEDING ECOLOGY OF THE GREEN CRAB, CARCINUS MAENAS (L., 1758) IN A TEMPERATE ESTUARY, PORTUGAL
}

\author{
BY
}

\author{
ALEXANDRA BAETA ${ }^{1,3}$ ), HENRIQUE N. CABRAL ${ }^{2}$ ), JOÃO C. MARQUES ${ }^{1}$ ) and \\ MIGUEL A. PARDAL ${ }^{1}$ ) \\ 1) IMAR - Institute of Marine Research, Department of Zoology, University of Coimbra, \\ P-3004-517 Coimbra, Portugal \\ 2) Instituto de Oceanografia, Faculdade de Ciências da Universidade de Lisboa, Campo Grande, \\ P-1749-016 Lisboa, Portugal
}

\begin{abstract}
The feeding ecology of Carcinus maenas was studied between June 2003 and June 2004 in three areas in the Mondego estuary, Portugal. Samples were collected monthly, during the night, at high water of spring tides using a $2 \mathrm{~m}$ beam trawl. Among 837 stomachs examined, 25 different food items were identified. Crangon crangon, Hediste diversicolor, and Teleostei were the most important food items by occurrence, numbers, and weight. As an opportunistic feeder, differences in diet found between areas and seasons reflected prey availability. No differences were found in prey selection according to sex and carapace width of individuals. The feeding intensity of moulting and ovigerous crabs was lower. The incidence of cannibalism was higher than reported in the literature. C. maenas seems to be a main top predator in the food web of the Mondego estuarine ecosystem.
\end{abstract}

\section{RESUMO}

A ecologia alimentar de Carcinus maenas foi estudada entre Junho de 2003 e Junho de 2004 em três locais no estuário do Mondego, Portugal. As amostras foram colhidas mensalmente, durante a noite, na vazante de marés vivas usando um arrasto de vara com $2 \mathrm{~m}$. Entre os 837 estômagos examinados, 25 itens alimentares diferentes foram identificados. Crangon crangon, Hediste diversicolor e Teleostei foram os itens alimentares mais importantes por ocorrência, número e peso. Sendo um consumidor oportunista, as diferenças na dieta encontradas entre locais e estações do ano refectem a disponibilidade das presas no meio. Não foram encontradas diferenças na selecção de presas de acordo com o sexo e a largura da carapaça dos indivíduos. A intensidade alimentar dos caranguejos em muda e fêmeas ovigeras foi baixa. A incidência de canibalismo foi mais elevada do que reportado na literatura. C. maenas parece ser um predador topo na teia alimentar do ecossistema estuarino do Mondego.

\footnotetext{
${ }^{3}$ ) Corresponding author; e-mail: asbaeta@ci.uc.pt

(C) Koninklijke Brill NV, Leiden, 2006

C Koninklijke Brill NV, Leiden, 2006
Also available online: www.brill.nl/cr
}

Crustaceana 79 (10): 1181-1193 


\section{INTRODUCTION}

The green crab, Carcinus maenas (Linnaeus, 1758), is a foraging, omnivorous predator, feeding on a wide variety of prey items (Crothers, 1967), in particular molluscs (Ropes, 1968; Elner, 1981), crustaceans (Gaudêncio, 1991), and polychaetes (Le Calvez, 1987). The species is mainly active at night and at high tide, and its diet can markedly change as a result of lower diversity and seasonal changes in the availability of its prey species (e.g., Ropes, 1968).

A few laboratory experiments have demonstrated that the availability of potential food items is not the only factor determining the diet of this crab. The species shows preference not only for the type of prey, but also for a certain size group. This preference is thought to be related to higher prey value or profitability, expressed as the net energy intake per unit of handling time: the Optimal Foraging Theory (Elner \& Hughes, 1978; Hughes \& Seed, 1981; Kaiser et al., 1993; Mascaró \& Seed, 2001).

Several studies have confirmed that crab predation is an important factor structuring marine benthic communities (e.g., Raffaelli et al., 1989; Grosholz et al., 2000). Predation by green crabs can influence the abundance and distribution of commercially important bivalve species (e.g., Leber, 1985; Sanchez-Salazar et al., 1987; Raffaelli et al., 1989).

The aim of the present study was to examine the feeding ecology of $C$. maenas in the Mondego estuary, in order to evaluate its importance in the estuarine food web, since this species is locally abundant and of economic interest.

\section{MATERIAL AND METHODS}

Study site

The Mondego estuary, a small temperate estuarine system on the western coast of Portugal (fig. 1), consists of two arms, North and South, with very different hydrological characteristics. The North arm is deeper (5 to $10 \mathrm{~m}$ during high tide, tidal range about 2 to $3 \mathrm{~m}$ ), and constitutes the principal navigation channel and the location of the Figueira da Foz harbour. The South arm is shallower ( 2 to $4 \mathrm{~m}$ deep during high tide) and is almost silted up in the upper zones, resulting in the freshwater outflow taking place mainly via the northern arm. Circulation in the southern arm is mostly dependent on the tides and on the freshwater input from the Pranto River, a small tributary of the Mondego. The discharge from this tributary is controlled by a sluice and is regulated according to the water needs of the rice fields in the Mondego Valley (Pardal et al., 2000, 2004; Marques et al., 2003; Cardoso et al., 2004). 


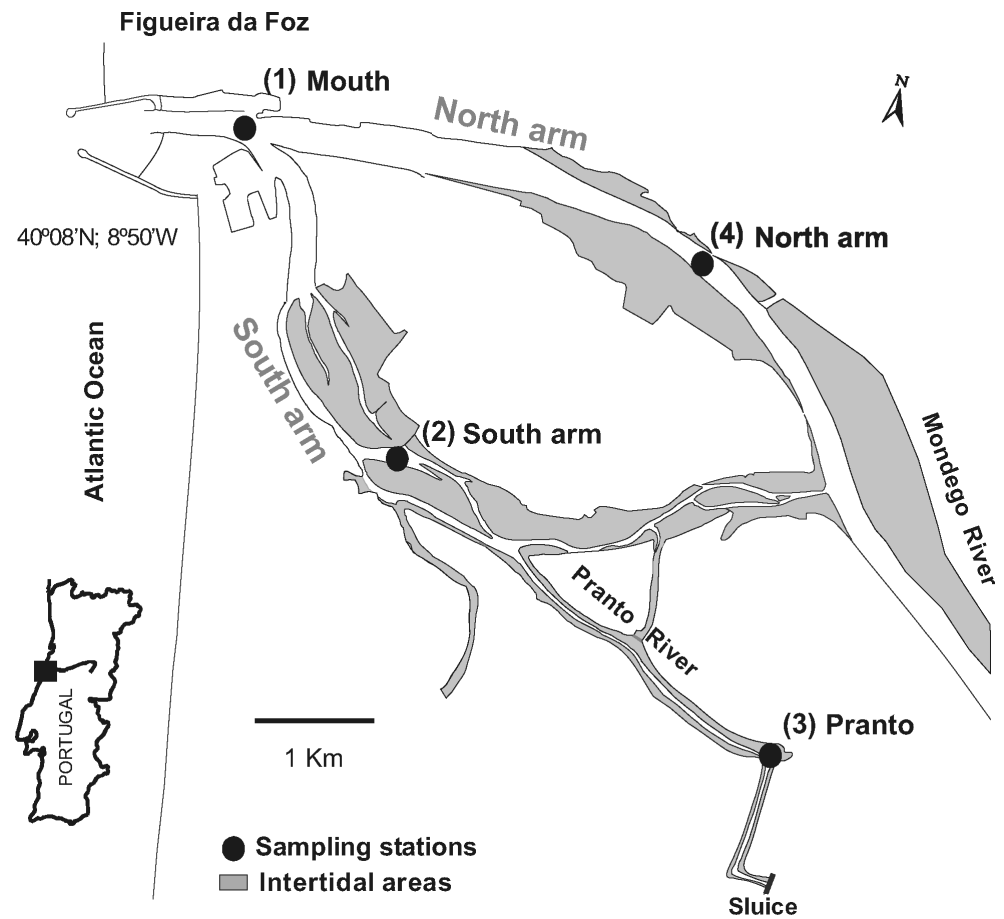

Fig. 1. The Mondego estuary, showing the location of the four sampling stations (Mouth, South arm, Pranto, and North arm).

As in many other estuaries, the south arm of the Mondego has undergone significant eutrophication due to organic enrichment (Pardal et al., 2000, 2004; Marques et al., 2003; Cardoso et al., 2004). The symptoms of such process include, among others, seasonal intertidal macroalgal blooms of Enteromorpha spp. (Pardal et al., 2000, 2004; Dolbeth et al., 2003; Marques et al., 2003; Cardoso et al., 2004; Verdelhos et al., 2005). A management programme is currently implemented, aiming at increasing the ecological quality of the system and at promoting the recovery of seagrass beds, which are currently restricted to the downstream areas of the estuary (Verdelhos et al., 2005).

\section{Sampling programme}

The population of Carcinus maenas was sampled monthly, from June 2003 to June 2004, at four stations (Mouth, South arm, Pranto, and North arm), using a $2 \mathrm{~m}$ beam trawl with a tickler chain and $5 \mathrm{~mm}$ mesh size in the cod end. All trawls were carried out during the night, at high water of spring tides. Since the population of $C$. maenas was very sparse in the north arm, the small number of individual collected there will not be taken in to account in the present work. 
Sediment samples were collected in the summer and autumn of 2003, and in the winter and spring of 2004, using a Van Veen dredge, in order to determine prey availability at the sampling stations.

\section{Laboratory procedures}

Crabs were counted, measured (carapace width, CW), and examined for sex, reproductive condition (occurrence of ovigerous females), and moulting stage. Stomachs were removed and the contents preserved in $4 \%$ buffered formalin for later identification. Diet characterization was based on these stomach contents. The stomach contents of 837 crabs (442 males and 395 females) were examined. Each prey item was identified to the lowest taxonomic level possible, counted, and weighed (wet weight).

\section{Data analysis}

The relative importance of each prey item in the diet was expressed as a percentage of the occurrence of food items in stomachs $\left(I_{O}\right)$, numerical abundance $\left(I_{N}\right)$, and weight $\left(I_{W}\right)$ (Hyslop, 1980).

A canonical correspondence analysis was used in order to evaluate the crabs' feeding patterns, and to relate age classes, sex, season, and sampling area with the food items. Computations were performed using CANOCO (Ter Braak \& Smilauer, 1998).

Prey abundance in the sediment was expressed as the number of individuals per $\mathrm{m}^{2}$. The numerical frequencies of prey according to the crab's age class, sex, season, and sampling station were compared using chi-square tests $\left(\chi^{2}\right)$.

Food selectivity was evaluated by comparing prey availability and diet composition in numerical terms, using Spearman rank correlations (Zar, 1996). Feeding activity was evaluated by the vacuity index $\left(I_{V}\right)$, defined as the percentage of empty stomachs (Hyslop, 1980).

\section{RESULTS}

General feeding habitats

Carcinus maenas chiefly ate Crustacea, mainly Crangon crangon (Linnaeus, 1758), Polychaeta, particulary Hediste diversicolor (O.F. Müller, 1776) and Teleostei (table I). These food items were the most important by occurrence $\left(I_{O}\right)$, number $\left(I_{N}\right)$, and weight $\left(I_{W}\right)$. Scrobicularia plana (Da Costa, 1778), C. maenas, and Pectinaria sp. were also common prey, but their index values were lower.

In the canonical correspondence analysis performed on the gravimetric index values, the first two axes accounted for $63 \%$ of the variance due to group-prey 
TABLE I

Occurrence $\left(I_{O}\right)$, numerical $\left(I_{N}\right)$, and gravimetric $\left(I_{W}\right)$ index values of prey found in stomachs of Carcinus maenas (L.) in the Mondego estuary

\begin{tabular}{|c|c|c|c|}
\hline \multirow[t]{2}{*}{ Prey taxon } & \multicolumn{3}{|c|}{ Indices } \\
\hline & $I_{O}$ & $I_{N}$ & $I_{W}$ \\
\hline \multicolumn{4}{|l|}{ Crustacea } \\
\hline Amphipoda n.i. & 2.27 & 2.08 & 0.31 \\
\hline Cumacea n.i. & 1.14 & 1.79 & 0.25 \\
\hline \multicolumn{4}{|l|}{ Decapoda } \\
\hline Carcinus maenas (Linnaeus, 1758) & 6.96 & 4.92 & 9.40 \\
\hline Crangon crangon (Linnaeus, 1758) & 21.82 & 18.93 & 22.70 \\
\hline Palaemon sp. & 1.28 & 0.92 & 1.21 \\
\hline Decapoda n.i. & 1.69 & 1.11 & 1.13 \\
\hline \multicolumn{4}{|l|}{ Mysidacea } \\
\hline Mesopodopsis slabberi (Van Benden, 1861) & 0.14 & 0.10 & 0.00 \\
\hline Mysidacea n.i. & 1.95 & 3.66 & 0.98 \\
\hline Crustacea n.i. & 3.39 & 2.42 & 1.27 \\
\hline \multicolumn{4}{|l|}{ Insecta } \\
\hline Diptera & 0.28 & 0.20 & 0.00 \\
\hline Insecta n.i. & 0.28 & 0.20 & 0.00 \\
\hline \multicolumn{4}{|l|}{ Mollusca } \\
\hline Bivalvia n.i. & 0.14 & 0.10 & 0.05 \\
\hline Cerastoderma edule (Linnaeus, 1758) & 1.42 & 1.32 & 0.79 \\
\hline Cerastoderma glaucum (Poiret, 1789) & 0.43 & 0.40 & 0.39 \\
\hline Mytilus galloprovincialis (Lamarck, 1819) & 0.14 & 0.10 & 0.00 \\
\hline Scrobicularia plana (Da Costa, 1778) & 13.21 & 9.26 & 8.92 \\
\hline \multicolumn{4}{|l|}{ Cephalopoda } \\
\hline Sepiola sp. & 0.28 & 0.20 & 1.06 \\
\hline \multicolumn{4}{|l|}{ Gastropoda } \\
\hline Gastropoda n.i. & 0.14 & 0.10 & 0.00 \\
\hline Hydrobia ulvae (Pennant, 1777) & 0.43 & 0.40 & 0.00 \\
\hline \multicolumn{4}{|l|}{ Polychaeta } \\
\hline Hediste diversicolor (O.F. Müller, 1776) & 17.90 & 15.58 & 14.83 \\
\hline Pectinaria sp. & 6.68 & 4.74 & 6.17 \\
\hline Polychaeta n.i. & 2.69 & 1.89 & 2.67 \\
\hline \multicolumn{4}{|l|}{ Teleostei } \\
\hline Gobiidae n.i. & 0.71 & 0.63 & 1.82 \\
\hline Teleostei n.i. & 25.53 & 19.36 & 25.51 \\
\hline Algae & 10.09 & 7.14 & 0.50 \\
\hline No. of samples & 704 & & \\
\hline No. of prey items & & 1004 & \\
\hline Total weight of prey (g) & & & 19.01 \\
\hline
\end{tabular}




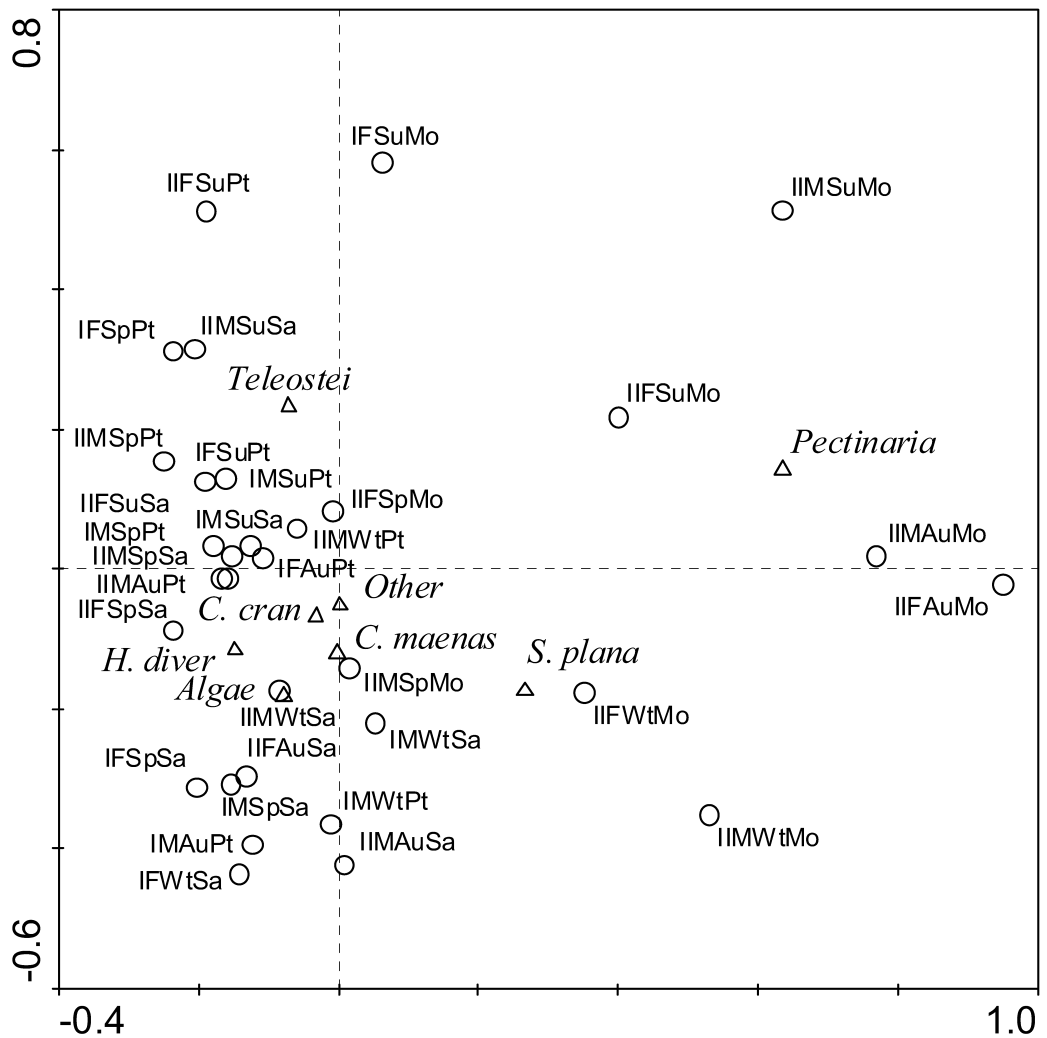

Fig. 2. Ordination diagram for the first two canonical axes of the canonical correspondence analysis performed on the gravimetric index values. Food items: Other, Algae, Carcinus maenas, Crangon crangon, Hediste diversicolor, Pectinaria sp., Scrobicularia plana, Teleostei. Age classes: I $<1$; II $>1$ years old. F, females; M, males. Seasons: Sp, spring; Su, summer; Au, autumn; Wt, winter. Stations: Mo, Mouth; Sa, South arm; Pt, Pranto.

item relations. The ordination diagram (fig. 2) shows the main feeding patterns of the $C$. maenas population representing the groups considered (age class, sex, season, and sampling stations) in relation to food items.

Crabs caught at the Mouth are found along the right edge of the diagram, associated with Pectinaria sp., mainly in summer and autumn, and with Scrobicularia plana, mainly in winter. The individuals from Pranto are found essentially in the upper left part of the diagram associated with Teleostei, mainly in spring and summer. Crabs from South arm are found mostly in the lower left corner of the diagram, associated with Hediste diversicolor, particularly in autumn and winter. In summer, the South arm crabs are associated with Teleostei. Crangon crangon is a very important prey item at all sampling stations and in all seasons, whilst the categories Algae and Others are the least important food items in the C. maenas diet. The incidence of cannibalism is high and occurs essentially at Pranto, mainly 
in spring and autumn. No difference according to the crab's sex and age classes appears to occur. Canonical correspondence analyses performed using the values of occurrence and of numerical indices were also made, with similar results as that of the gravimetric index diagram. For this reason, just one of those diagrams is presented. In order to better understand these feeding patterns, the crab's diet was examined separately according to age class, sex, season, and sampling station (see below).

Diet variation with crabs age class and sex

The population size structure had already been studied and age classes $(0+, 0++$, $1+, 2+, 3+, 4+$ years old) had been identified for both sexes (Baeta et al., 2005), assuming that $C$. maenas reaches sexual maturity within the 30 to $40 \mathrm{~mm}$ (carapace width) size interval (Broekhuysen, 1936; Klein Breteler, 1976).

No differences were found between juveniles ( $<1$ year old) and adults ( $>1$ year old) $\left(\chi_{0.05(7)}^{2}=4.294 ; p>0.05\right.$ to $\left.I_{N}\right)$ (fig. 3A). However, juveniles showed lower levels of Teleostei in their diet and higher levels of small crustaceans, such as Amphipoda and Cumacea, in comparison to adult crabs. No differences were found between sexes $\left(\chi_{0.05(7)}^{2}=2.166 ; p>0.05\right.$ to $\left.I_{N}\right)$ (fig. 3B).

Diet variation with season and sampling station

Carcinus maenas' diet differed according to season $\left(\chi_{0.05(7)}^{2}=18.415\right.$; $p<0.05)$ and sampling area $\left(\chi_{0.05(14)}^{2}=74.682 ; p<0.05\right)$ (fig. 4A, B). In spring and summer it showed higher levels of Teleostei and lower of S. plana, in terms of occurrence, numbers, and weight. At the Mouth there was a higher consumption of Bivalvia, mainly $S$. plana (high $I_{O}, I_{N}$, and $I_{W}$ comparative to the other areas), and the prey item Pectinaria sp. was only found at this station. At South arm, the prey $H$. diversicolor and Algae were more consumed than in the other sampling areas. At Pranto, the most important food item were Teleostei (high $I_{O}, I_{N}$, and $\left.I_{W}\right)$.

\section{Food selectivity and feeding activity}

The Spearman rank correlation showed that diet did not reflect prey availability at any of the three sampling stations $(0.15,0.52$, and 0.44 for Mouth, South arm, and Pranto, respectively; $p>0.05$ ) (table II). Vacuity was low at all times (mean values of 13, 15, and 19\% for the Mouth, South arm and Pranto, respectively). Vacuity levels were higher in moulting crabs and ovigerous females $(45 \%$ and $43 \%$, respectively). 


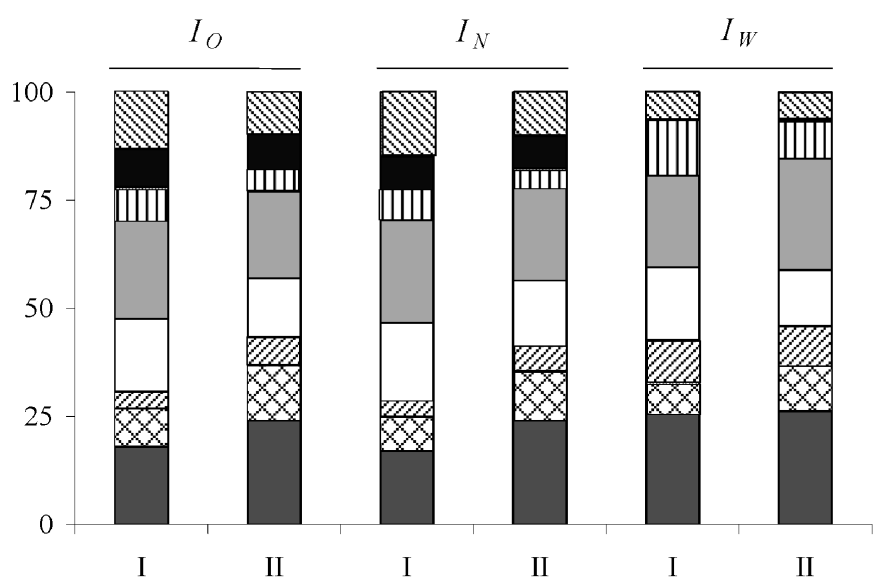

A

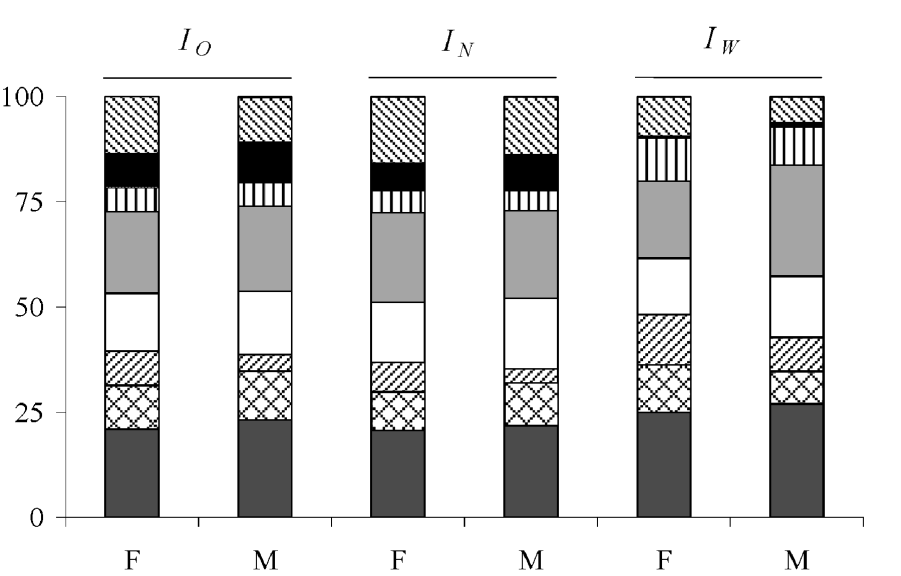

$\mathrm{B}$

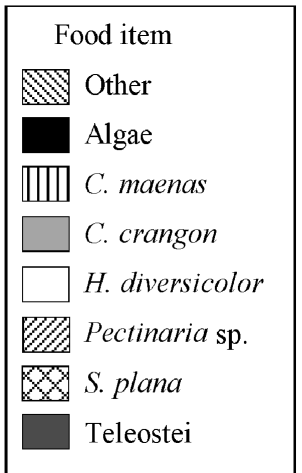

Age classes:

I $-<1$ year old

II $->1$ year old

Sexes:

$\mathrm{F}-$ Females

M- Males

Fig. 3. Relative importance of food items in the diet of Carcinus maenas (L., 1758), according to: A, carapace width; B, sex; based on: $I_{O}$, occurrence index; $I_{N}$, numerical index; $I_{W}$, gravimetric index. 

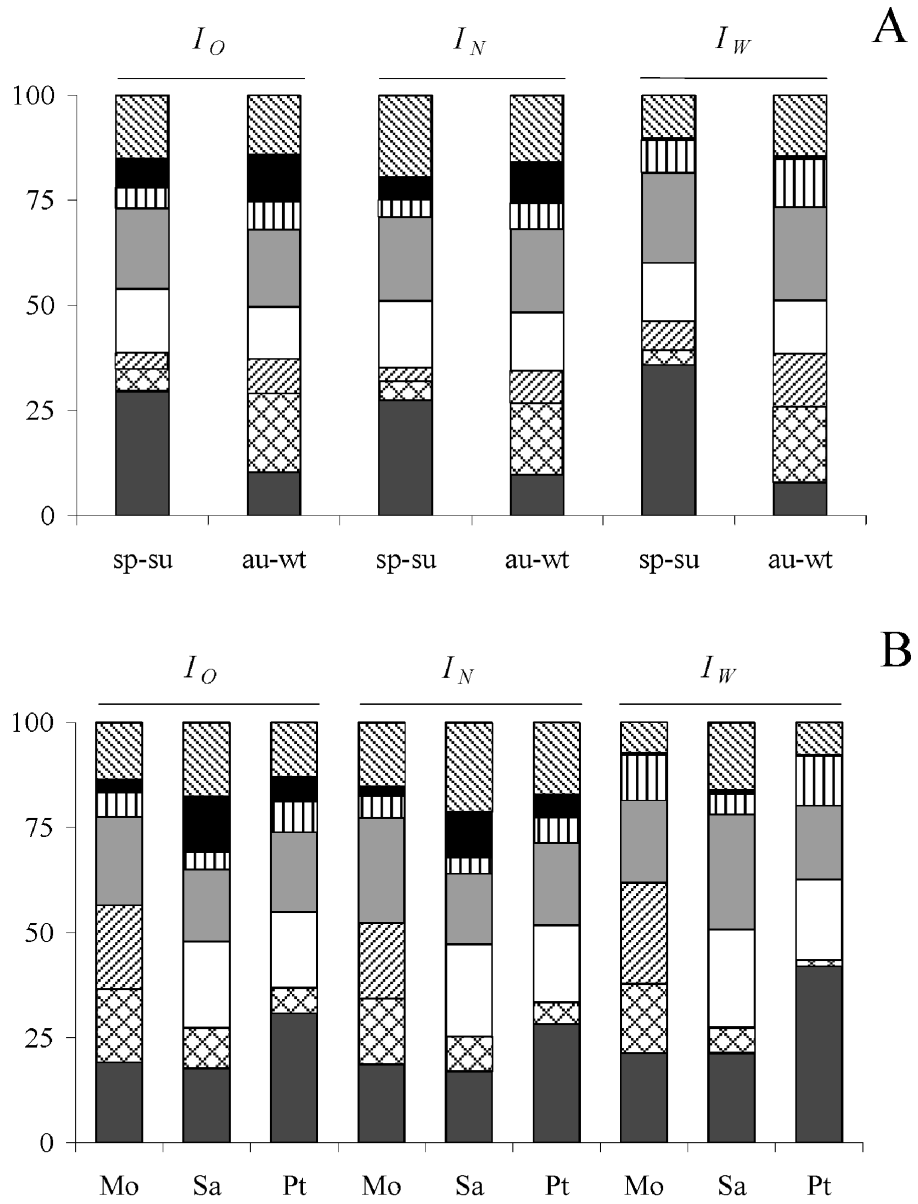

\begin{tabular}{|c|c|}
\hline \multicolumn{2}{|c|}{ Food item } \\
\hline & Other \\
\hline & Algae \\
\hline & C. maenas \\
\hline & C. crangon \\
\hline & H. diversicolor \\
\hline & Pectinaria sp. \\
\hline 8. & S. plana \\
\hline & Teleostei \\
\hline
\end{tabular}

Seasons:

sp-su - spring-summer

au-wt - autumn-winter

Sampling - stations:

Mo - Mouth

$\mathrm{Sa}-$ South arm

Pt - Pranto

Fig. 4. Relative importance of food items in the diet of Carcinus maenas (L., 1758), according to: A, seasons; B, sampling stations; based on: $I_{O}$, occurrence index; $I_{N}$, numerical index; $I_{W}$, gravimetric index. 
TABLE II

Ranks of abundance of benthic prey of Carcinus maenas (L.) at the sampling stations in the Mondego estuary (ranks are in decreasing order of importance)

\begin{tabular}{lccc}
\hline & Mouth & South arm & Pranto \\
\hline Amphipoda & 1 & 7 & 8 \\
Carcinus maenas (Linnaeus, 1758) & 8 & 6 & 5 \\
Crangon crangon (Linnaeus, 1758) & 6 & 5 & 4 \\
Hediste diversicolor (O.F. Müller, 1776) & 7 & 3 & 2 \\
Mollusca & 3 & 4 & 6 \\
Mysidacea & 5 & 2 & 7 \\
Polychaeta & 4 & 1 & 3 \\
Scrobicularia plana (Da Costa, 1778) & 2 & & 1 \\
\hline
\end{tabular}

DISCUSSION

Previous studies on Carcinus maenas have reported that the most important prey items are Bivalvia (Ropes, 1969; Elner, 1981; Raffaelli et al., 1989; Le Roux et al., 1990), Crustacea (Albertini-Berhaut, 1973; Gaudêncio et al., 1991), and Polychaeta (Le Calvez, 1987). Our study revealed that C. maenas from the Mondego estuary has a less diversified diet, probably due to a different composition of the benthic fauna, but also here Crustacea, Polychaeta, and Teleostei are the most important food items in occurrence, numbers, and weight alike.

This species is thought to be a voracious, opportunistic predator. In the present study, this species showed preferences for a few slow-moving benthic invertebrates, probably due to their energetic value or their abundance in the intertidal areas (Cardoso et al., 2004; Pardal et al., 2004; Verdelhos et al., 2005). For instance, the average energy density ( $\mathrm{JJ}^{-1}{ }^{-1}$ AFDW) of Crangon crangon and Hediste diversicolor is higher than that of Scrobicularia plana or C. maenas $(22,22.5,21.8$, and $21.5 \mathrm{kJ.g}^{-1}$ AFDW, respectively) (Zwarts \& Wanink, 1993). Moreover, these prey items, especially juvenile crustaceans, are more abundant in the intertidal areas and thus available for predation, since the green crab is thought to undertake intertidal migrations mainly at high tide (e.g., Hunter \& Naylor, 1993; Warman et al., 1993).

Gaudêncio et al. (1991) reported that fish are a common food item in this species' diet, yet their results did not show a higher occurrence of that prey, as presented in this study. Although it is not easy, nor always possible, to identify the species of fish from the jaws and vertebrae they may well have been benthic species such as gobies (Pomatoschistus spp.). These are known to co-exist with C. maenas in their nursery areas, and are more abundant in spring and summer at the Pranto site (Leitão et al., 2006). Thus, the higher occurrence of fish in the diet of $C$. maenas during spring and summer coincides with their abundance. 
Several authors consider that portunid crabs feed selectively on algae (Ropes, 1969; Le Calvez, 1987; Le Roux et al., 1990). In this study, the amount of algae found in the stomachs suggests that algae were ingested accidentally along with other food items. Nevertheless, the incidence of cannibalism was higher than what is found in literature (e.g., Ropes, 1969; Gaudêncio, 1991). This is believed to occur because this species is very abundant in this small estuary (Baeta et al., 2005), and hence frequently encounters its conspecifics when searching for prey.

No differences were found between the two age classes and sexes, probably due to the fact that they do-occur in the same areas. Of course, larger crabs ate larger prey, in order to maximize net energy intake when feeding. Phill (1985) reported that juveniles (crabs $<30 \mathrm{~mm}$ ) are mainly detritivorous, results that are quite different from what is presented in this study, probably due to crab's opportunistic behaviour.

Seasonal and spatial variations in the diet reflected seasonal and spatial variations in the availability of food types in each particular season and habitat, and thus the crab's opportunistic foraging behaviour.

A higher proportion of empty stomachs was found in moulting crabs and in ovigerous females. These crabs are generally less active and feed less in order to avoid predation, as they are highly attractive to predators at that time (Reid et al., 1997). The Pranto was the sampling station with a higher $I_{V}$ value, since the proportion of moulting crabs increased from downstream to upstream areas.

The results of this study strongly suggest that despite the diversity in its diet in the Mondego estuary, Carcinus maenas preferentially consumed several extremely abundant prey species such as Scrobicularia plana and Amphipoda, i.e., showing a preference for those types of prey that live in the surface of the sediment and are more easy subjects to predation. In conclusion, $C$. maenas seems to assume an important position in the food web of the Mondego estuary, not only because it is able to feed on a variety of surface or subsurface organisms that have themselves different feeding strategies, but also on organisms that live above the surface, such as fishes and decapods. In this estuary, C. maenas was not found to be an important prey for species of fish or birds (Múrias et al., 1996; Lopes et al., 2000). It can hence be considered a main top-predator in the food web of the Mondego estuarine ecosystem, playing an important role through influencing the structure of the marine benthic community in this area.

\section{ACKNOWLEDGEMENTS}

The present study was carried out within the framework of the research project "Dynamic model of stress induced changes on benthic communities" (POCTI/MGS/37431/2001) funded by the Portuguese FCT. A special thanks to all colleagues that helped during field work. 


\section{REFERENCES}

Albertini-Berhaut, J., 1973. Biologie des stades juvéniles des Teleostéens Mugilidae Mugil auratus Risso, 1810, Mugil capito Cuvier, 1829 et Mugil saliens Risso, 1810. I. Régime alimentaire. Aquaculture, 2: 251-276.

Baeta, A., H. N. Cabral, J. M. Neto, J. C. Marques \& M. A. Pardal, 2005. Biology, population dynamics and secondary production of the green crab, Carcinus maenas (L.) in a temperate estuary. Est. coast. Shelf Sci., 65: 43-52.

BRAaK, C. J. F. TER \& P. SMilauer, 1998. CANOCO reference manual and user's guide to CANOCO for Windows: software for Canonical Community Ordination (version 4): 1-352. (Microcomputer Power, Ithaca, NY).

BroekhuYSEN, G. J., 1936. On development, growth and distribution of Carcinides maenas (L.) Arch. Néerlandaise de Zool., 2: 257-399.

CAlvez, J. CH. LE, 1987. Location of the chore crab Carcinus maenas L., in the food web of a managed estuary ecosystem: the Rance basin (Brittany, France). Invest. Pesq., Barcelona, 51 (1): 431-442.

Cardoso, P. G., M. A. Pardal, A. I. Lillebø, S. M. Ferreira, D. Raffaelli \& J. C. MARQUeS, 2004. Dynamic changes in seagrass assemblages under eutrophication and implications for recovery. Journ. exp. mar. Biol. Ecol., 302: 233-248.

Crothers, J. H., 1967. The biology of the shore crab Carcinus maenas (L.). II. The life of the adult crab. Field Stud., 2 (5): 579-617.

Dolbeth, M., M. A. Pardal, A. I. Lilleb $\emptyset$, U. Azeiteiro \& J. C. Marques, 2003. Short- and long-term effects of eutrophication on the secondary production of an intertidal macrobenthic community. Mar. Biol., Berlin, 143: 1229-1238.

Elner, R. W., 1981. Diet of green crab Carcinus maenas (L.) from Port Hebert, southwestern Nova Scotia. Journ. Shellfish Res., 1 (1): 89-94.

Elner, R. W. \& R. N. Hughes, 1978. Energy maximization in the diet of the shore crab Carcinus maenas. Journ. Anim. Ecol., 47: 103-116.

Gaudêncio, M. J., M. T. Guerra, P. R. Almeida, F. M. Moreira, J. L. Costa \& C. Assis, 1991. Estrutura e funcionamento das comunidades animais do estuário do Tejo (Bentónicas, Ictiológicas e Ornitológicas), suas relações com alterações antropogénicas. Povoamentos macrozoobentónicos. Projecto $\mathrm{n}^{0}$ 87294. Área mar., 2: 1-69.

Grosholz, E. D., G. M. Ruiz, C. A. Dean, K. A. Shirley, J. L. Maron \& P. G. Connors, 2000. The impacts of a nonindigenous marine predator in a California bay. Ecology, 81 (5): 1206-1224.

Hughes, R. N. \& R. SEed, 1981. Size selection of mussels by the blue crab Callinectes sapidus: energy maximizer or time minimizer? Mar. Ecol. Progr. Ser., 6: 83-89.

Hunter, E. \& E. NAYLOR, 1993. Intertidal migration by the shore crab Carcinus maenas. Mar. Ecol. Progr. Ser., 101: 131-138.

HYSLOP, E. J., 1980. Stomach contents analysis: a review of methods and their application. Journ. Fish Biol., 17: 415-429.

KAiser, M. J., R. N. Hughes \& R. N. Gibson, 1993. Factors affecting diet selection in the shore crab, Carcinus maenas (L.). Anim. Behav., 45: 83-92.

Klein Breteler, W. C. M., 1976. Settlement, growth and production of the shore crab, Carcinus maenas, on tidal flats in the Dutch Wadden Sea. Netherlands Journ. Sea Res., 10 (3): 354-376.

LEBER, K. M., 1985. The influence of predatory decapods, refuge and microhabitat selection on seagrass communities. Ecology, 66: 1951-1964.

Leitão, R., F. Martinho, J. M. Neto, H. Cabral, J. C. Marques \& M. A. Pardal, 2006. Feeding ecology, population struture and distribution of Pomatoschistus microps (Krøyer, 1838) and Pomatoschistus minutes (Pallas, 1770) in a temperate estuary, Portugal. Est. coast. Shelf Sci., 66: 231-239. 
Lopes, R. J., M. A. PARdAl \& J. C. MARques, 2000. Impact of macroalgal blooms and wader predation on intertidal macroinvertebrates: experimental evidence from the Mondego estuary (Portugal). Journ. exp. mar. Biol. Ecol., 249: 165-179.

Marques, J. C., S. N. Nielsen, M. A. Pardal \& S. E. Jørgensen, 2003. Impact of eutrophication and river management within a framework of ecosystem theories. Ecol. Model., 166: $147-168$.

MASCARÓ, M. \& R. SEED, 2001. Foraging behaviour of Carcinus maenas (L.) and Cancer pagurus L. Mar. Biol., Berlin, 139: 1135-1145.

Múrias, T., J. A. Cabral, J. C. Marques \& J. D. Goss-Custard, 1996. Short-term effects of intertidal macroalgal blooms on the macrohabitat selection and feeding behaviour of wading birds in the Mondego estuary. Est. coast. Shelf Sci., 43: 677-688.

Pardal, M. A., P. G. Cardoso, J. P. Sousa, J. C. Marques \& D. Raffaelli, 2004. Assessing environmental quality: a novel approach. Mar. Ecol. Progr. Ser., 267: 1-8.

Pardal, M. A., J. C. Marques, I. Metelo, A. I. Lilleb $\varnothing$ \& M. R. Flindt, 2000. Impact of eutrophication on the life cycle, population dynamics and production of Ampithoe valida (Amphipoda) along an estuarine spatial gradient (Mondego estuary, Portugal). Mar. Ecol. Progr. Ser., 196: 207-219.

PHILL, L., 1985. Food selection and consumption of mobile epibenthic fauna in shallow marine areas. Mar. Ecol. Progr. Ser., 22: 179-196.

Raffaelli, D., A. Conacher, H. Mclachlan \& C. Ernes, 1989. The role of epibenthic crustacean predators in an estuarine food web. Est. coast. Shelf Sci., 28: 149-160.

Reid, D. G., P. Abelló, M. J. Kaiser \& C. G. WARMAn, 1997. Carapace colour, inter-moult duration and physiological ecology of the shore crab Carcinus maenas. Est. coast. Shelf Sci., 44: $203-211$.

Ropes, J. W., 1968. The feeding habits of the green crab Carcinus maenas. Fish. Bull., U.S., 67: 183-203.

RouX, P. J. LE, G. M. BRANCH \& A. P. JOSKA, 1990. On the distribution, diet and possible impact of the invasive European shore crab Carcinus maenas (L.) along the South African coast. South Africa. Journ. mar. Sci., 9: 85-93.

SAnChez-SAlazar, M. E., C. L. Griffiths \& R. Seed, 1987. The effect of size and temperature on the predation of cockles Cerastoderma edule (L.) by the shore crab Carcinus maenas (L.). Journ. exp. mar. Biol. Ecol., 3: 181-193.

Verdelhos, T., J. M. Neto, J. C. Marques \& M. A. Pardal, 2005. The effect of eutrophication abatement on the bivalve Scrobicularia plana. Est. coast. Shelf Sci., 63: 261-268.

WARMAN, C. G., D. G. REID \& E. NAYLOR, 1993. Variation in the tidal migratory behaviour and rhythmic light-responsiveness in the shore crab, Carcinus maenas. Journ. mar. biol. Ass. U. K., 73: $355-364$.

ZAR, J., 1996. Biostatistical analysis (3rd ed.). (Prentice Hall, Englewood Cliffs).

ZWARTS, L. \& J. H. WANINK, 1993. How the food supply harvestable by waders in the Wadden Sea depends on the variation in energy density, body weight, biomass, burying depth and behaviour of tidal-flat invertebrates. Netherlands Journ. Sea Res., 31 (4): 441-476.

First received 29 March 2006

Final version accepted 2 May 2006. 